\title{
Gender differences in health insurance coverage in China
}

\author{
Mei Zhou', Shaoyang Zhao ${ }^{2^{*}}$ (i) and Zhi Zhao ${ }^{2}$
}

\begin{abstract}
Background: China initiated a reform of the health insurance system in the late 1990s. The new insurance, Urban Employee Basic Medical Insurance (UEBMI), is employment-based, which makes it more difficult than it used to be for those unemployed or informal employed (most of whom are women) to be covered by health insurance.

Methods: Based on three large sample of micro datasets, we first use statistical methods to identify gender differences in health insurance. Next, we construct a logistic regression model to capture the differences in insurance coverage across age groups using the parameter of interaction terms for gender and age groups.

Results: Based on data from a demographic survey that covers a large sample, we find that in the below 50 (in 2005) or 60 (in 2015) years age group, the coverage gap of UEBMI between men and women was relatively smaller, while a larger disparity existed in the above 50 (in 2005) or 60 (in 2015) group. Moreover, gender differences in health insurance were more significant in the low-education group, while no gender differences were found in the high-education group.

Conclusions: This paper explains the gender gap in health insurance and the reason for the wider gap among older people. Our study indicates that because the UEBMI in China mainly covers people with formal jobs, a lower labor participation rate (even much lower in formal jobs) of women has led to their greater difficulty in obtaining health insurance. Since the older women's greater difficulty in obtaining jobs or susceptibility to lay-offs during the period of the UEBMI's implementation, the possibility of being covered was even much lower. In fact, it was because of the combined effects of the UEBMI system and the labor market condition at that time that older women had a lower proportion of being covered under the UEBMI.
\end{abstract}

Keywords: Gender gap, Health insurance coverage, Health insurance reform, Education

\section{Background}

The Chinese government has been trying to build a universal public social health insurance (SHI) system since the early 2000s, and has essentially achieved universal SHI coverage [1-4]. The ambitious SHI initiative consists of three key programs: the Urban Employee Basic Medical Insurance (UEBMI) for the urban employed, initiated in 1998; the New Cooperative Medical Scheme (NCMS) for rural residents, established in 2003; and the

\footnotetext{
* Correspondence: zhaoshaoyang@scu.edu.cn

${ }^{2}$ School of Economics, Sichuan University, Chengdu, China

Full list of author information is available at the end of the article
}

Urban Resident Basic Medical Insurance (URBMI), covering urban residents without formal employment (including children, the elderly, and other unemployed), launched in 2007. While enrollment under the UEBMI is compulsory for urban employees, the NCMS and the URBMI are voluntary insurance programs. By 2018, more than $97 \%$ of the entire Chinese population had SHI [5]. However, obvious inequities remain in the insurance system [6-9].

On the one hand, the UEBMI has the highest level of financing and benefits-significantly higher than those of the other two; On the other hand, there are inequities in the duration of health insurance coverage. It was not

C The Author(s). 2021 Open Access This article is licensed under a Creative Commons Attribution 4.0 International License, which permits use, sharing, adaptation, distribution and reproduction in any medium or format, as long as you give appropriate credit to the original author(s) and the source, provide a link to the Creative Commons licence, and indicate if changes were made. The images or other third party material in this article are included in the article's Creative Commons licence, unless indicated otherwise in a credit line to the material. If material is not included in the article's Creative Commons licence and your intended use is not permitted by statutory regulation or exceeds the permitted use, you will need to obtain permission directly from the copyright holder. To view a copy of this licence, visit http://creativecommons.org/licenses/by/4.0/ The Creative Commons Public Domain Dedication waiver (http://creativecommons.org/publicdomain/zero/1.0/) applies to the data made available in this article, unless otherwise stated in a credit line to the data. 
until the establishment of URBMI in 2007 that the accessibility of health insurance to urban residents was improved, especially for the unemployed women. In the last decade, health insurance coverage has resulted in large gender inequities, which may further affect the accessibility of health resources and health status. Therefore, this paper focuses on the gender difference in UEBMI coverage.

The roots of the inequity in China's health insurance lies in the flawed system design of the UEBMI system reform. The UEBMI's features of being employment-based and not including other family members stems from the 1994 reform of the health insurance system [10]. Before the reform, the healthcare insurance system in the era of the planned economy consisted of labor insurance and public health services. Public health services were mainly provided to part of the government staffs, whereas labor insurance covered general enterprise employees and their family members.

In 1994 China initiated the reform of the medical insurance system by implementing an SHI system compatible with the market economy-the UEBMI system. After several years of pilot work in Zhenjiang (Jiangsu province) and Jiujiang (Jiangxi province), this system was ultimately carried out nationwide in 1998. The UEBMI mainly covers the employed (excluding family members). Compared with the labor insurance system, the biggest change under the UEBMI is the requirement of being linked to one's work unit, which makes it more difficult than it used to be for those unemployed or informal employed (most of whom are women) to be covered by medical insurance. Under the labor insurance system, a work unit's medical insurance covered family members, although covering only half of their medical expenses. Meanwhile, under the new health insurance system, it is difficult for someone without a formal job to be covered by the UEBMI. Thus, compared with men, the situation has gotten tougher for women than ever before.

From the perspective of the UEBMI system reform in China, we investigate whether the basic health insurance coverage rate for women is lower than that for men and how this gender gap varies across the age groups. As for younger women and men, due to their higher employment rate, a higher proportion of them obtain the UEBMI. Meanwhile, for older women and men, health insurance is also available, provided they originally have a job. And it is mainly the group without a job that faces more difficulties in obtaining health insurance, within which women ought to account for the largest proportion. Women's lower labor participation rate suggests that they have significantly lower access to health care than men do, especially the elderly. This is the gender difference in health insurance coverage that is examined in this study.
Based on the census data, this paper describes in detail the gap between women's and men's health insurance coverage. Our most important finding is that this gap manifests itself primarily in terms of age, where there is a large and persistent gender gap in the older age groups, and that the gender gap in health care coverage for younger people is not large due to the relatively high participation rate of Chinese women in the labor force. We describe the institutional context in which this disparity arises and analyze the potential impact of gender disparities in health insurance on health care utilization and health.

This study first confirms the existence of a gender gap in health insurance coverage based on a survey of a large population sample. Thereafter, we compare the changes in these gaps before and after the 1998 UEBMI reform using the China Health and Nutrition Survey (CHNS) data. Next, we discuss the possible reasons for inequities in the health insurance system and the potential impact on healthcare utilization and health status. Finally, we draw our conclusions and provide recommendations.

\section{Methodology}

\section{Data sources}

In this study, we used three datasets to validate gender differences in health insurance: one-fifth of the $2005 \mathrm{Na}$ tional Sample Survey of $1 \%$ of the population (randomly chosen; Sample A), the 2015 survey data of $1 \%$ of the population in Sichuan Province (Sample B), and the 1991-2011 survey data from the CHNS (Sample C).

We began by using Sample A. China conducts a population census every 10 years, and a large-scale population survey-the $1 \%$ of the population sample survey-is conducted between the two censuses. Sample A covers 2, 585,481 individuals in 31 provinces, autonomous regions, and municipalities in Chinese mainland. Populations in both agricultural and non-agricultural areas are included in the survey. The survey covers respondents' personal characteristics, including gender, age, and educational level, as well as other information such as the type of health insurance, health status, and so on. In the subsequent analysis, we further used Sample B. Samples B comprises $1 \%$ of the population of Sichuan Province only and comprises 1 million respondents.

To test our conjecture, we used Sample C, which covers eight waves of pre- and post-1998 reform data, enabling us to make a comparison of the changes in health insurance between men and women. The corresponding survey for Sample $C$ covered nine provinces, which vary considerably in terms of geography, economic development, public resources, and health indicators. A stratified sampling scheme was used to stratify districts in the nine provinces by income, with four districts in each province randomly selected. The entire 
survey consists of about 4400 households, covering about 19,000 people. The survey participants are also tracked in follow-up surveys and some of them who could no longer be tracked due to migration and other reasons are replenished by adding new samples.

\section{Variables}

The key dependent variable (Insurance) in our analysis relates to whether a person is covered by the UEBMI. Insurance is a binary dummy variable that is 1 if the individual is enrolled in UEBMI and 0 if they are enrolled in NCMS, URBMI, or do not have any insurance. It should be noted that this study focuses on whether they are covered by UEBMI and therefore classifies individuals who are NCMS, URBMI, or do not have any insurance as one category. In 2005, only two years after the establishment of NCMS, the participation rate was low and there were more uninsured individuals; by 2015, the percentage of uninsured was very low, and most people have been covered by UEBMI, NCMS or URBMI.

Age is an important grouping variable; thus, we removed samples under the age of 15 and separated the sample into age groups with 10-year intervals. We also conducted a heterogeneity analysis of the sample according to education level and compared the variability in insurance coverage based on education levels. In the regression analysis, we controlled for the sample's personal characteristics such as gender, Hukou, marital status, and ethnicity. Hukou (a unique household registration system in China) is a dummy variable that refers to whether the survey respondent is registered in a rural or urban area. Classifications for marital status include married, unmarried, and widowed. Ethnicity is a dummy variable that denotes whether the sample is an ethnic minority or not.

\section{Estimation models}

Since Insurance is a binary variable, we constructed a logistic regression model to investigate further the gender gap of health insurance coverage. The model is presented in Eq. (1) below:

$$
y_{i}=\beta_{1} \text { age }_{i} * \text { female }_{i}+\beta_{2} \text { age }_{i}+\beta_{3} \text { female }_{i}+X_{i} \gamma
$$

where the subscripts $i$ denotes individual; $\beta$ and $\gamma$ are the estimated parameters, in which $\beta_{1}$ is our key parameter that captures the differences in insurance coverage across age groups. The dependent variable, Insurance, denotes whether individual $i$ is covered by UEBMI; age denotes the age group of individual $i$; female denotes the gender of individual $i$; and $X$ denotes the other control variables, including Hukou, educational level, marital status, and regional fixed effects. The error term $u$ denotes the random variability not explained by the model.

\section{Results}

Gender gap in health insurance coverage: based on survey data of $1 \%$ of the population in 2005 (sample a) In the first stage of the analysis, we used Sample A. Figure 1 shows that for all age groups, the proportion of women covered by health insurance was lower than that of men. This was due to the higher labor participation rate of men. Meanwhile, by age group, the proportions of men and women with insurance coverage revealed different distribution trends. For men, the proportion of those covered by health insurance increased continually with age; while for women aged below 50 years, the proportion increased continually with age as well. However, this proportion kept declining continuously for the older women (aged above 50 years) and more obviously for

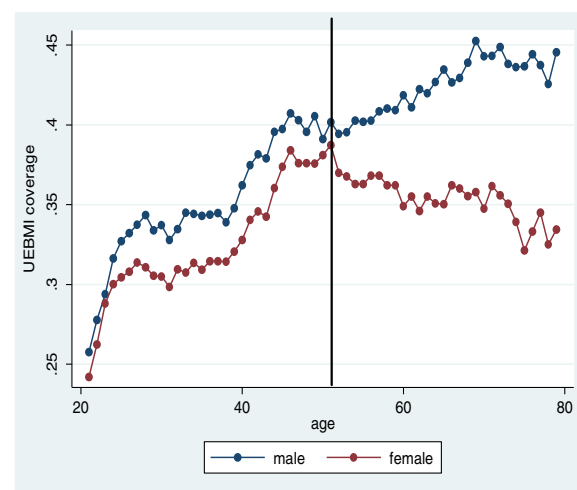

(a) Population Census in 2005

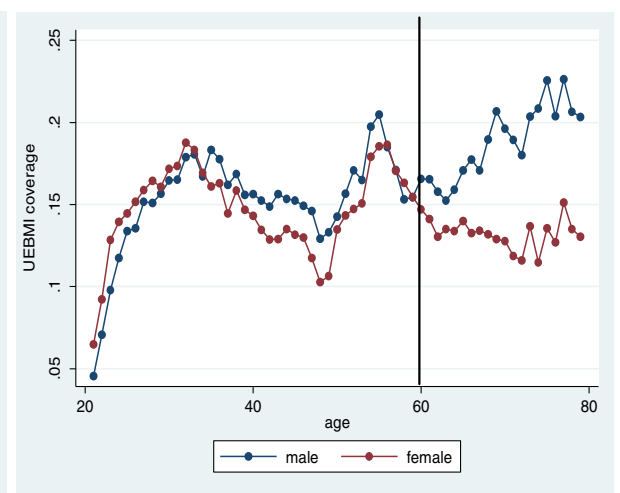

(b) Population Census in and 2015

Fig. 1 The Urban Employee Basic Medical Insurance (UEBMI) Coverage Rate: Based on Survey Data of 1\% of the Population in 2005 and 2015 
those aged above 60 years. Considering the educational level (Fig. 2), the UEBMI coverage rates for men and women aged below 50 years were almost equivalent. However, for the groups aged over 50, for women, the proportion of those with insurance coverage was significantly lower than that for men only in the less educated group (primary school graduates and below), and this gap tended to widen with age. In general, this suggests that education level might have influenced the low rate of insurance coverage for the older people, while this effect of education did not exist for the younger people.
Next, in the regression estimation, we classified the population by age, with $[50,55)$ being the control group. Table 1 reports the result of the regression, in which columns 1 and 2 correspond to regression models with and without control variables (such as education), respectively. As shown in Table 1, when variables such as the educational level were not controlled for, the proportion of women being covered by UEBMI in all age groups was always lower than that of men (the coefficients of both female and female*age are significantly positive). This is consistent with the previous results as shown in Fig. 2 .

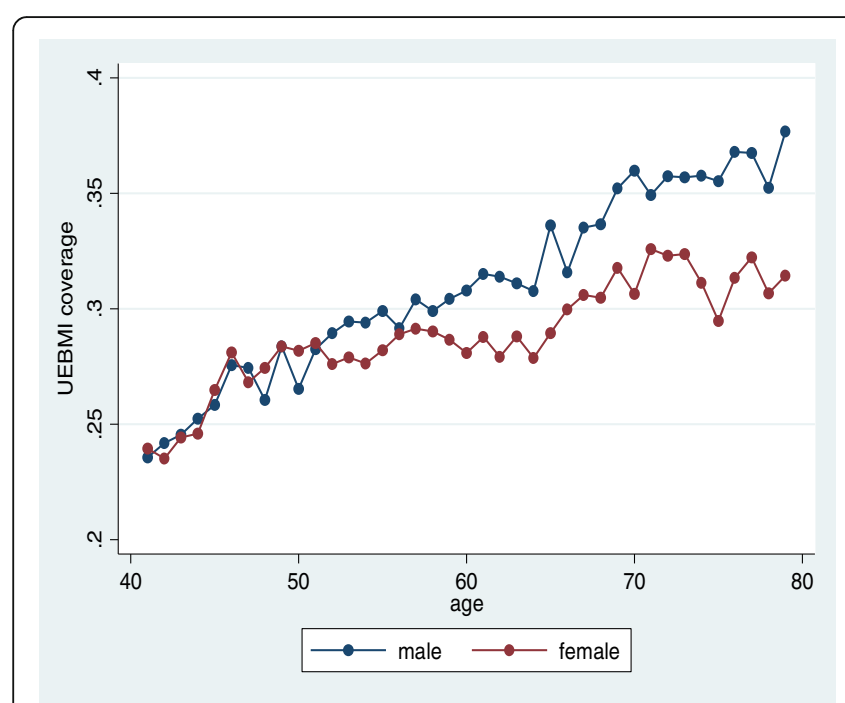

(a) Primary School Graduates and below

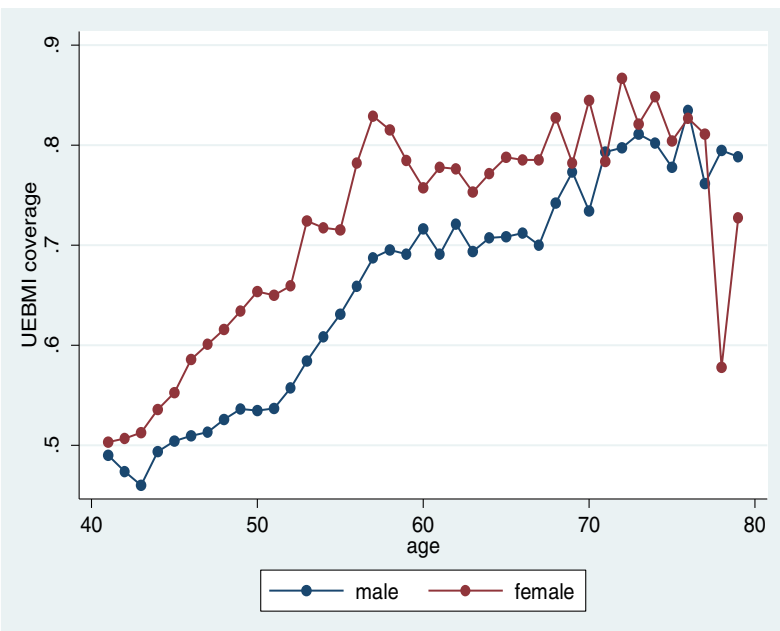

(c) Senior Middle School Graduates

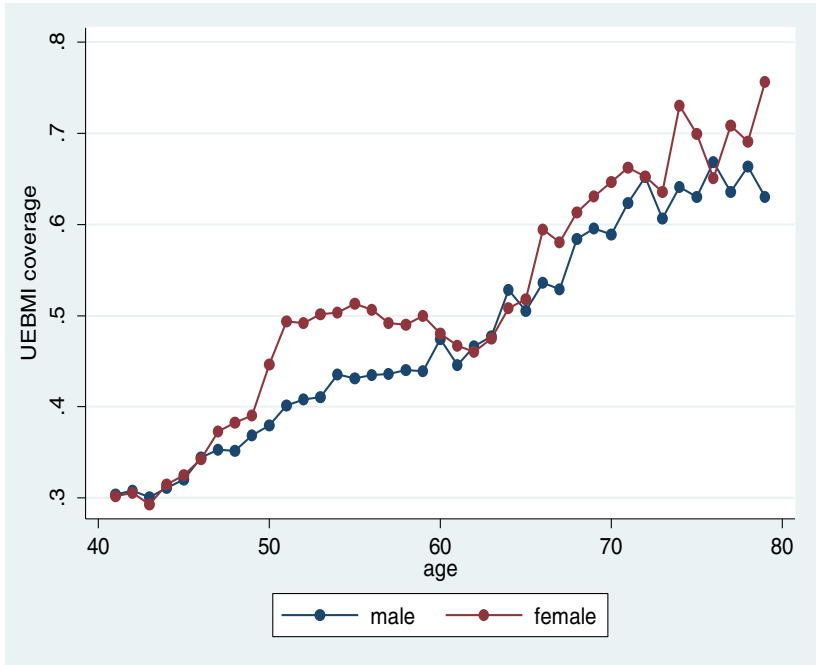

(b) Junior Middle School Graduates

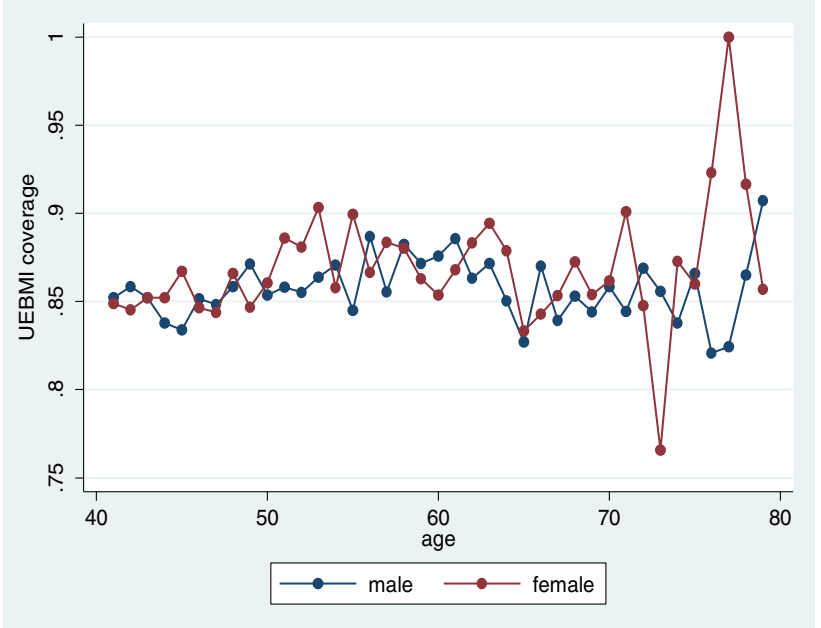

(d) College Graduates and above

Fig. 2 The Urban Employee Basic Medical Insurance (UEBMI) Coverage Rate in 2005 by Educational Levels 


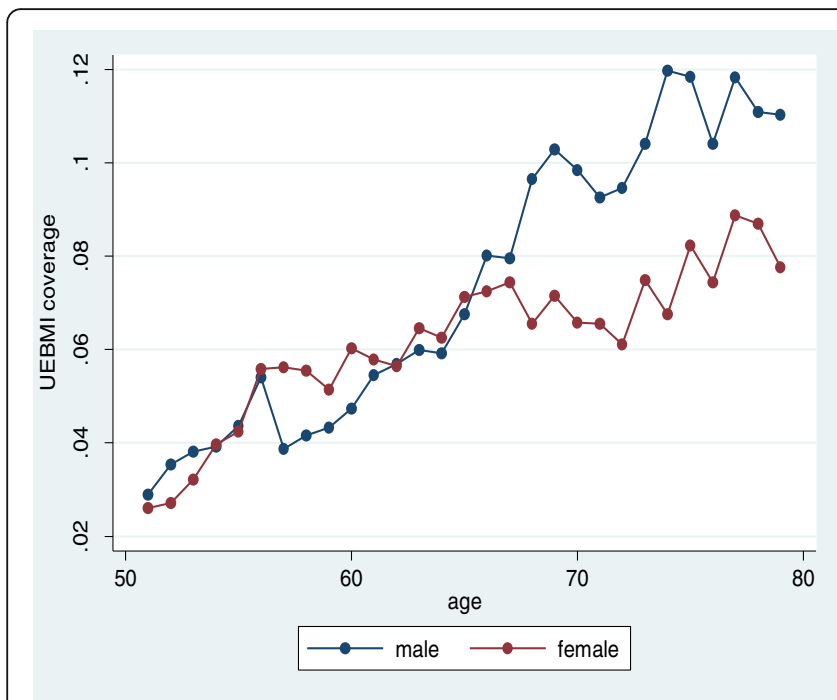

(a) Primary School Graduates and below

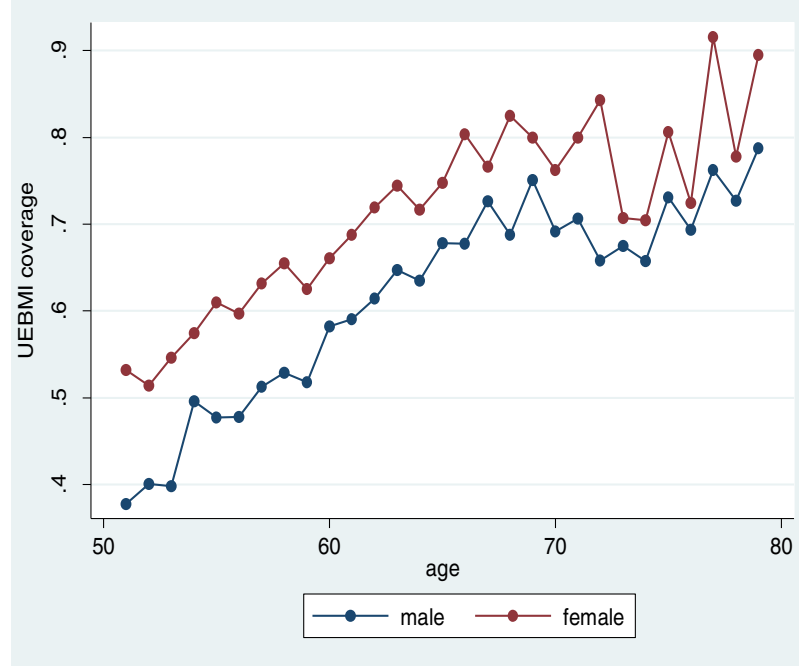

(c) Senior Middle School Graduates

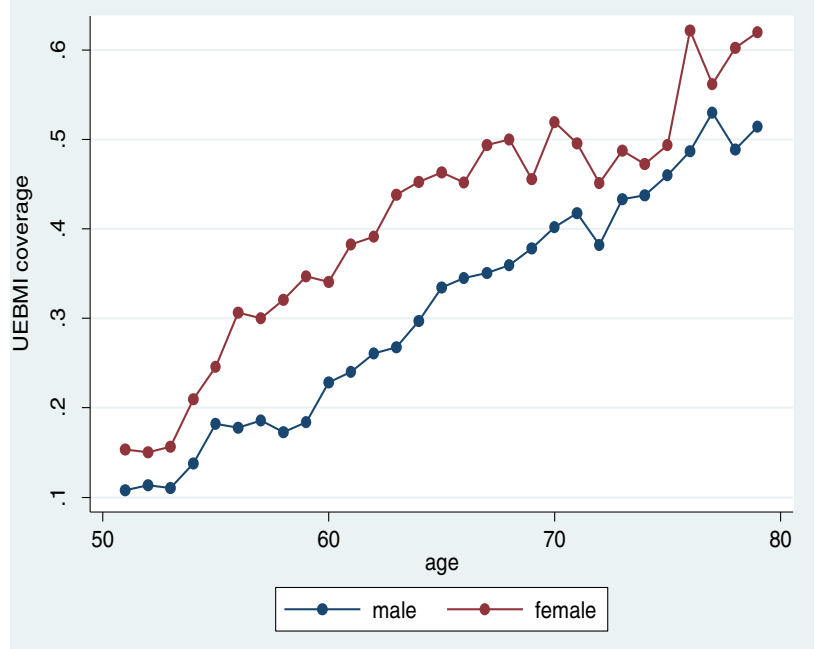

(b) Junior Middle School Graduates

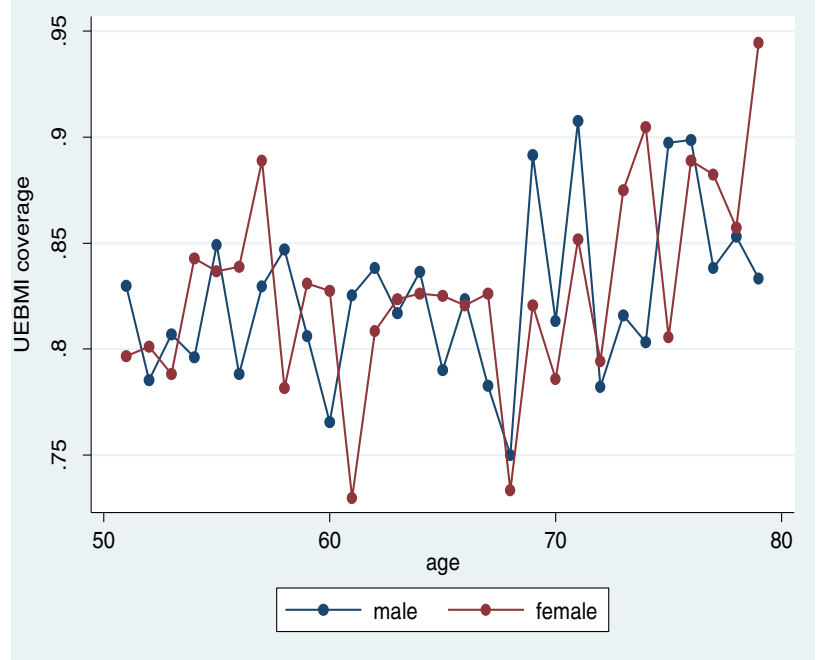

(d) College Graduates and above

Fig. 3 The Urban Employee Basic Medical Insurance (UEBMI) Coverage Rate in 2015 by Educational Levels

Moreover, when controlling for variables such as the educational level, the coefficient of women became significantly positive, indicating a higher proportion of women being covered by health insurance in the age group of [50, 55) as compared with men. However, since the other interaction term coefficients of gender and age are both significantly negative and the absolute values are greater than the coefficient of female, this indicates that generally, the women's health insurance coverage rate was still significantly lower than that of men. By further observing the coefficients of the interaction term, we can clearly find their obvious changes below and above the age bracket of $[50,55)$. Below this age bracket, there is no clear trend in these coefficients of the interaction term, while above this age bracket they continue to increase in absolute value. This means that the health insurance coverage gap between women and men has been continuously widening for those above the age of 55 .

Taking a step further, we examined the gap of health insurance coverage between men and women considering different education levels (see Table 2). The results of the regression show that it was only in the groups of less educated (primary school graduates and below) 
Table 1 Results of Different Estimation Methods: Based on Population Census in 2005

\begin{tabular}{|c|c|c|c|}
\hline \multicolumn{4}{|c|}{$\begin{array}{l}\text { Urban Employee Basic Medical Insurance (UEBMI) } \\
\text { (Dependent Variable: Covered by UEBMI or Not) }\end{array}$} \\
\hline & (1) & (2) & (3) \\
\hline Female & $\begin{array}{l}-0.0937^{* * *} \\
(0.0098)\end{array}$ & $\begin{array}{l}-0.125^{* * *} \\
(0.0106)\end{array}$ & $\begin{array}{l}0.0548^{* * *} \\
(0.0110)\end{array}$ \\
\hline $\begin{array}{l}\text { Female *age } \\
{[15,25)}\end{array}$ & $\begin{array}{l}0.0629^{* * *} \\
(0.0135)\end{array}$ & $\begin{array}{l}0.0690^{* * *} \\
(0.0149)\end{array}$ & $\begin{array}{l}-0.148^{* * *} \\
(0.0161)\end{array}$ \\
\hline $\begin{array}{l}\text { Female *age } \\
{[25,35)}\end{array}$ & $\begin{array}{l}-0.0395^{* * *} \\
(0.0119)\end{array}$ & $\begin{array}{l}-0.0300^{* *} \\
(0.0131)\end{array}$ & $\begin{array}{l}-0.199^{* * *} \\
(0.0138)\end{array}$ \\
\hline $\begin{array}{l}\text { Female *age } \\
{[35,45)}\end{array}$ & $\begin{array}{l}-0.0498^{* * *} \\
(0.0115)\end{array}$ & $\begin{array}{l}-0.0484^{* * *} \\
(0.0127)\end{array}$ & $\begin{array}{l}-0.119^{* * *} \\
(0.0132)\end{array}$ \\
\hline $\begin{array}{l}\text { Female *age } \\
{[45,50)}\end{array}$ & $\begin{array}{l}-0.00956 \\
(0.0139)\end{array}$ & $\begin{array}{l}-0.00845 \\
(0.0151)\end{array}$ & $\begin{array}{l}-0.0191 \\
(0.0158)\end{array}$ \\
\hline $\begin{array}{l}\text { Female *age } \\
{[55,60)}\end{array}$ & $\begin{array}{l}-0.0810^{* * *} \\
(0.0151)\end{array}$ & $\begin{array}{l}-0.130^{* * *} \\
(0.0163)\end{array}$ & $\begin{array}{l}-0.121^{* * *} \\
(0.0169)\end{array}$ \\
\hline $\begin{array}{l}\text { Female *age } \\
{[60,65)}\end{array}$ & $\begin{array}{l}-0.196^{* * *} \\
(0.0166)\end{array}$ & $\begin{array}{l}-0.269^{* * *} \\
(0.0179)\end{array}$ & $\begin{array}{l}-0.250^{* * *} \\
(0.0186)\end{array}$ \\
\hline $\begin{array}{l}\text { Female *age } \\
{[65,70)}\end{array}$ & $\begin{array}{l}-0.239^{* * *} \\
(0.0175)\end{array}$ & $\begin{array}{l}-0.322^{* * *} \\
(0.0188)\end{array}$ & $\begin{array}{l}-0.249^{* * * *} \\
(0.0197)\end{array}$ \\
\hline $\begin{array}{l}\text { Female *age } \\
{[70,75)}\end{array}$ & $\begin{array}{l}-0.288^{* * *} \\
(0.0189)\end{array}$ & $\begin{array}{l}-0.384^{* * *} \\
(0.0203)\end{array}$ & $\begin{array}{l}-0.277^{* * *} \\
(0.0211)\end{array}$ \\
\hline $\begin{array}{l}\text { Female *age } \\
{[75,80)}\end{array}$ & $\begin{array}{l}-0.358^{* * *} \\
(0.0227)\end{array}$ & $\begin{array}{l}-0.472^{* * *} \\
(0.0241)\end{array}$ & $\begin{array}{l}-0.344^{* * *} \\
(0.0253)\end{array}$ \\
\hline $\begin{array}{l}\text { Female *age } \\
{[80+1,00)}\end{array}$ & $\begin{array}{l}-0.426^{* * *} \\
(0.0253)\end{array}$ & $\begin{array}{l}-0.531^{* * *} \\
(0.0270)\end{array}$ & $\begin{array}{l}-0.426^{* * *} \\
(0.0284)\end{array}$ \\
\hline$x$ & No & No & YES \\
\hline City & No & YES & YES \\
\hline Observations & $1,904,763$ & $1,904,763$ & $1,903,627$ \\
\hline
\end{tabular}

Notes: 1) The control age group is $[50,55)$

2) The control variable $X$ includes registered permanent residence, marital status, educational level, nationality, and so on. City represents fixed effects after controlling for cities

3 ) $* * * * * *$ indicate statistical significance at the 1,5 , and $10 \%$ levels, respectively. The numbers in parentheses are standard errors of robust SE

people that this phenomenon of continuous widening of the gap existed. In groups of senior middle school graduates and below, women's health insurance coverage rates were all lower than that of men's but did not show an expanding trend. Among higher educated people, women's health insurance coverage rates were not necessarily lower than that of men's, signifying that the gender gap in health insurance was not obvious among the old, higher educated people.

\section{Gender gap in health insurance coverage: based on} survey data of $1 \%$ of the population in 2015 (sample B) In the following analysis, we further used Sample B.

Figure 1 indicates that the results are similar to those generated from using Sample A, except that the turning point here has shifted to the age of 60 . Below the age of 60 , men and women's UEBMI coverage rates were
Table 2 Results of Different Estimation Methods: Based on Population Census in 2015

Dependent Variable: Covered by the Urban Employee Basic Medical Insurance (UEBMI) or Not

\begin{tabular}{|c|c|c|c|c|}
\hline & $\begin{array}{l}\text { (1) Primary } \\
\text { School } \\
\text { Graduates } \\
\text { and below }\end{array}$ & $\begin{array}{l}\text { (2) Junior } \\
\text { Middle } \\
\text { School } \\
\text { Graduates }\end{array}$ & $\begin{array}{l}\text { (3) Senior } \\
\text { Middle } \\
\text { School } \\
\text { Graduates }\end{array}$ & $\begin{array}{l}\text { (4) } \\
\text { University } \\
\text { Graduates } \\
\text { and above }\end{array}$ \\
\hline Female & $\begin{array}{l}-0.0241 \\
(0.0170)\end{array}$ & $\begin{array}{l}0.195^{* * *} \\
(0.0191)\end{array}$ & $\begin{array}{l}0.229 * * * \\
(0.0340)\end{array}$ & $\begin{array}{l}0.211^{* * *} \\
(0.0758)\end{array}$ \\
\hline $\begin{array}{l}\text { Female *age } \\
{[15,25)}\end{array}$ & $\begin{array}{l}-0.0506 \\
(0.0337)\end{array}$ & $\begin{array}{l}-0.282^{* * *} \\
(0.0239)\end{array}$ & $\begin{array}{l}-0.375^{* * *} \\
(0.0425)\end{array}$ & $\begin{array}{l}-0.219^{* * *} \\
(0.0842)\end{array}$ \\
\hline $\begin{array}{l}\text { Female *age } \\
{[25,35)}\end{array}$ & $\begin{array}{l}-0.0156 \\
(0.0263)\end{array}$ & $\begin{array}{l}-0.343^{* * *} \\
(0.0224)\end{array}$ & $\begin{array}{l}-0.548^{* * *} \\
(0.0384)\end{array}$ & $\begin{array}{l}-0.323^{* * *} \\
(0.0792)\end{array}$ \\
\hline $\begin{array}{l}\text { Female *age } \\
{[35,45)}\end{array}$ & $\begin{array}{l}0.0592^{* * *} \\
(0.0230)\end{array}$ & $\begin{array}{l}-0.304^{* * *} \\
(0.0218)\end{array}$ & $\begin{array}{l}-0.373^{* * *} \\
(0.0376)\end{array}$ & $\begin{array}{l}-0.183^{* *} \\
(0.0814)\end{array}$ \\
\hline $\begin{array}{l}\text { Female *age } \\
{[45,50)}\end{array}$ & $\begin{array}{l}0.0753^{* * *} \\
(0.0271)\end{array}$ & $\begin{array}{l}-0.223^{* * *} \\
(0.0267)\end{array}$ & $\begin{array}{l}-0.168^{* * *} \\
(0.0410)\end{array}$ & $\begin{array}{l}-0.169^{*} \\
(0.0992)\end{array}$ \\
\hline $\begin{array}{l}\text { Female *age } \\
{[55,60)}\end{array}$ & $\begin{array}{l}-0.0753^{* * *} \\
(0.0246)\end{array}$ & $\begin{array}{l}-0.130^{* * *} \\
(0.0325)\end{array}$ & $\begin{array}{l}0.0693 \\
(0.0612)\end{array}$ & $\begin{array}{l}-0.134 \\
(0.123)\end{array}$ \\
\hline $\begin{array}{l}\text { Female *age } \\
{[60,65)}\end{array}$ & $\begin{array}{l}-0.152^{* * *} \\
(0.0262)\end{array}$ & $\begin{array}{l}-0.418^{* * *} \\
(0.0391)\end{array}$ & $\begin{array}{l}-0.202^{* * *} \\
(0.0670)\end{array}$ & $\begin{array}{l}-0.167 \\
(0.133)\end{array}$ \\
\hline $\begin{array}{l}\text { Female *age } \\
{[65,70)}\end{array}$ & $\begin{array}{l}-0.176^{* * *} \\
(0.0263)\end{array}$ & $\begin{array}{l}-0.295^{* * *} \\
(0.0515)\end{array}$ & $\begin{array}{l}-0.134 \\
(0.0826)\end{array}$ & $\begin{array}{l}-0.197 \\
(0.133)\end{array}$ \\
\hline $\begin{array}{l}\text { Female *age } \\
{[70,75)}\end{array}$ & $\begin{array}{l}-0.182^{* * *} \\
(0.0272)\end{array}$ & $\begin{array}{l}-0.283^{* * *} \\
(0.0708)\end{array}$ & $\begin{array}{l}-0.186 \\
(0.125)\end{array}$ & $\begin{array}{l}-0.255 \\
(0.174)\end{array}$ \\
\hline $\begin{array}{l}\text { Female *age } \\
{[75,80)}\end{array}$ & $\begin{array}{l}-0.285^{* * *} \\
(0.0312)\end{array}$ & $\begin{array}{l}-0.180 \\
(0.111)\end{array}$ & $\begin{array}{l}-0.573^{* * *} \\
(0.170)\end{array}$ & $\begin{array}{l}0.395 \\
(0.295)\end{array}$ \\
\hline $\begin{array}{l}\text { Female *age } \\
{[80+, 100)}\end{array}$ & $\begin{array}{l}-0.380^{* * *} \\
(0.0339)\end{array}$ & $\begin{array}{l}-0.847^{* * *} \\
(0.136)\end{array}$ & $\begin{array}{l}-0.675^{* * *} \\
(0.210)\end{array}$ & $\begin{array}{l}-0.271 \\
(0.335)\end{array}$ \\
\hline$x$ & YES & YES & YES & YES \\
\hline County & YES & YES & YES & YES \\
\hline Observations & 771,963 & 755,007 & 248,055 & 128,602 \\
\hline
\end{tabular}

Notes: 1) The control age group is $[50,55)$

2) The control variable $X$ and fixed effects of cities have been added to all analyses

$3{ }^{* *}, *^{*}, *$ indicate statistical significance at the 1, 5, and $10 \%$ levels, respectively. The numbers in parentheses are standard errors of robust SE

almost equivalent, and the coverage rate for young women was even higher than that for men. Meanwhile, the proportion of women aged above 60 covered under UEBMI was much lower than that of men. Considering the level of education (Fig. 3), the coverage rates for men and women below 60 were almost equivalent and not influenced by the level of education. Meanwhile, for those aged over 60 , only for the less educated groups (primary school graduates and below) had a significantly lower coverage of women than men, and this gap continued to grow with age.

We applied model (1) on Sample B to perform the same regression and report the corresponding results in Tables 3 and 4 . As seen from the tables, for those below the age bracket of $[60,65)$, there is no clear trend in these interaction term coefficients, but the coefficients continuously increase (with a negative sign) for those 
Table 3 Gender Gap in Health Insurance Coverage: Based on Population Census in 2015

\begin{tabular}{|c|c|c|c|}
\hline \multicolumn{4}{|c|}{$\begin{array}{l}\text { Urban Employee Basic Medical Insurance (UEBMI) } \\
\text { (Dependent Variable: Covered by UEBMI or Not) }\end{array}$} \\
\hline & (1) & (2) & (3) \\
\hline Female & $\begin{array}{l}-0.177^{* * *} \\
(0.0226)\end{array}$ & $\begin{array}{l}-0.258^{* * *} \\
(0.0241)\end{array}$ & $\begin{array}{l}0.240^{* * *} \\
(0.0270)\end{array}$ \\
\hline $\begin{array}{l}\text { Female *age } \\
{[15,25)}\end{array}$ & $\begin{array}{l}0.526^{* * *} \\
(0.0344)\end{array}$ & $\begin{array}{l}0.558^{* * *} \\
(0.0366)\end{array}$ & $\begin{array}{l}-0.0568 \\
(0.0401)\end{array}$ \\
\hline $\begin{array}{l}\text { Female *age } \\
{[25,35)}\end{array}$ & $\begin{array}{l}0.238^{* * *} \\
(0.0269)\end{array}$ & $\begin{array}{l}0.255^{* * *} \\
(0.0289)\end{array}$ & $\begin{array}{l}-0.232^{* * *} \\
(0.0328)\end{array}$ \\
\hline $\begin{array}{l}\text { Female *age } \\
{[35,45)}\end{array}$ & $\begin{array}{l}0.0418 \\
(0.0264)\end{array}$ & $\begin{array}{l}0.0716^{* *} \\
(0.0282)\end{array}$ & $\begin{array}{l}-0.244^{* * *} \\
(0.0319)\end{array}$ \\
\hline $\begin{array}{l}\text { Female *age } \\
{[45,50)}\end{array}$ & $\begin{array}{l}-0.0382 \\
(0.0294)\end{array}$ & $\begin{array}{l}0.00757 \\
(0.0314)\end{array}$ & $\begin{array}{l}-0.229^{* * *} \\
(0.0350)\end{array}$ \\
\hline $\begin{array}{l}\text { Female *age } \\
{[50,55)}\end{array}$ & $\begin{array}{l}0.0610^{* *} \\
(0.0306)\end{array}$ & $\begin{array}{l}0.104^{* * *} \\
(0.0327)\end{array}$ & $\begin{array}{l}-0.0182 \\
(0.0365)\end{array}$ \\
\hline $\begin{array}{l}\text { Female *age } \\
{[55,60)}\end{array}$ & $\begin{array}{l}0.179^{* * *} \\
(0.0335)\end{array}$ & $\begin{array}{l}0.202^{* * *} \\
(0.0358)\end{array}$ & $\begin{array}{l}0.165^{* * *} \\
(0.0405)\end{array}$ \\
\hline $\begin{array}{l}\text { Female *age } \\
{[65,70)}\end{array}$ & $\begin{array}{l}-0.190^{* * *} \\
(0.0349)\end{array}$ & $\begin{array}{l}-0.211^{* * *} \\
(0.0372)\end{array}$ & $\begin{array}{l}-0.2211^{* * *} \\
(0.0416)\end{array}$ \\
\hline $\begin{array}{l}\text { Female *age } \\
{[70,75)}\end{array}$ & $\begin{array}{l}-0.371^{* * *} \\
(0.0389)\end{array}$ & $\begin{array}{l}-0.386^{* * *} \\
(0.0412)\end{array}$ & $\begin{array}{l}-0.386^{* * *} \\
(0.0472)\end{array}$ \\
\hline $\begin{array}{l}\text { Female *age } \\
{[75,80)}\end{array}$ & $\begin{array}{l}-0.373^{* * *} \\
(0.0436)\end{array}$ & $\begin{array}{l}-0.411^{* * *} \\
(0.0460)\end{array}$ & $\begin{array}{l}-0.294^{* * *} \\
(0.0543)\end{array}$ \\
\hline $\begin{array}{l}\text { Female *age } \\
{[80+, 100)}\end{array}$ & $\begin{array}{l}-0.707^{* * *} \\
(0.0464)\end{array}$ & $\begin{array}{l}-0.693^{* * *} \\
(0.0491)\end{array}$ & $\begin{array}{l}-0.454^{* * *} \\
(0.0572)\end{array}$ \\
\hline$x$ & No & YES & YES \\
\hline County & No & No & YES \\
\hline Observations & 838,544 & 838,544 & 838,544 \\
\hline
\end{tabular}

Notes: 1) The control age group is $[60,65)$

2) The control variable $X$ includes registered permanent residence, marital status, educational level, nationality, and so on. County represents fixed effects after controlling for counties

3 ) $* * * * * *$ indicate statistical significance at the 1,5 , and $10 \%$ levels,

respectively. The numbers in parentheses are standard errors of robust SE

above this age bracket. This indicates that the gap in UEBMI coverage rates between women and men has been getting wider and wider for those above the age of 60. Moreover, considering the level of education, the regression analysis shows that this phenomenon of continuous increase in insurance coverage gap for the [60, 65) age group and above only exists among the less educated population (primary school graduates and below).

Combining the results above, the study using Sample $B$ yielded almost the same results compared with the analysis based on Sample A. The only difference is the age at which the change in the gender gap in health insurance coverage occurred, which increased from age 50 to age 60 . This suggests that the situation (i.e., failing to get insurance coverage) has not changed 10 years later for part of the women aged above 50 .

2) The control variable $X$ and fixed effects of counties have been added to all analyses.
3) $* * * * *$ indicate statistical significance at the 1,5 , and $10 \%$ levels, respectively. The numbers in parentheses are standard errors of robust SE.

\section{Gender insurance gap before and after the implementation of the UEBMI reform}

Before the UEBMI reform in 1998, labor insurance, in effect, had covered family dependents. Thus, women, even though without a job, were able to obtain medical insurance benefits through the coverage of their working spouse. However, after the reform, the UEBMI's feature of being tied to work and not including other family members, made it harder than before for these unemployed women to obtain health insurance, which might have led to a widening of the gender gap in health insurance coverage. To verify this conjecture, we used Sample C, covering data before and after the 1998 reform, which enabled us to compare changes in health insurance between men and women.

First, the changes in the UEBMI coverage rate from 1991 to 2011 reappear in Fig. 4 (what should be noted here is that we combined labor insurance and various forms of employee medical insurance modes before 1998 into UEBMI for a comparison before and after that year). Figure 4 shows that there was a significant decline in the health insurance coverage rates for all age groups before 2000 but these began to increase rapidly starting from the implementation of the UEBMI. In 2011, the UEBMI had already covered $25 \%$ of the population.

Meanwhile, Fig. 5 shows no obvious difference in health insurance coverage rates between men and women among the investigated population in 1991 and 1993. However, the increasingly apparent gender gap was observed in the survey samples of 1997 and later, in 2000, 2004, 2006 and 2009, this gap mainly existed among the older population.

\section{Discussion}

Possible reasons for gender difference in health insurance coverage

The analysis shows that there were significant gender differences in health insurance, especially among the elderly, because of the unique health insurance system in China. The health insurance reform in 1998, which tied health insurance to work, resulted in more unemployed women lacking access to health insurance. According to a study based on the 1998 and 2003 National Health Service Survey data by Xu et.al [11], inequities in access to health insurance has intensified among different populations since 1997 because of the UEBMI reform. Moreover, women are significantly less likely to be insured compared to the pre-reform period. Theoretically, the unemployed or informal employed can also be enrolled in the UEBMI, except that they must bear a higher contribution. According to the regulation, "For the self- 
Table 4 Gender Gap in Health Insurance Coverage in 2015 by Educational Levels

\begin{tabular}{|c|c|c|c|c|}
\hline & $\begin{array}{l}\text { (1) Primary School } \\
\text { Graduates and below }\end{array}$ & $\begin{array}{l}\text { (2) Junior Middle } \\
\text { School Graduates }\end{array}$ & $\begin{array}{l}\text { (3) Senior Middle School and Technical } \\
\text { Secondary School Graduates }\end{array}$ & $\begin{array}{l}\text { (4) University } \\
\text { Graduates and } \\
\text { above }\end{array}$ \\
\hline Female & $\begin{array}{l}0.0157 \\
(0.0427)\end{array}$ & $\begin{array}{l}0.385^{* * *} \\
(0.0442)\end{array}$ & $\begin{array}{l}0.188^{* *} \\
(0.0938)\end{array}$ & $\begin{array}{l}-0.141 \\
(0.180)\end{array}$ \\
\hline $\begin{array}{l}\text { Female } \\
\text { *age[15,25) }\end{array}$ & $\begin{array}{l}-0.200 \\
(0.341)\end{array}$ & $\begin{array}{l}-0.435^{* * *} \\
(0.0868)\end{array}$ & $\begin{array}{l}-0.0729 \\
(0.105)\end{array}$ & $\begin{array}{l}0.517^{* * *} \\
(0.184)\end{array}$ \\
\hline $\begin{array}{l}\text { Female } \\
{ }^{*} \text { age[25,35) }\end{array}$ & $\begin{array}{l}-0.181 \\
(0.135)\end{array}$ & $\begin{array}{l}-0.468^{* * *} \\
(0.0592)\end{array}$ & $\begin{array}{l}-0.246^{* *} \\
(0.0992)\end{array}$ & $\begin{array}{l}0.249 \\
(0.182)\end{array}$ \\
\hline $\begin{array}{l}\text { Female } \\
{ }^{*} \text { age[35,45) }\end{array}$ & $\begin{array}{l}-0.214^{* * *} \\
(0.0730)\end{array}$ & $\begin{array}{l}-0.422^{* * *} \\
(0.0512)\end{array}$ & $\begin{array}{l}-0.0973 \\
(0.0990)\end{array}$ & $\begin{array}{l}0.193 \\
(0.185)\end{array}$ \\
\hline $\begin{array}{l}\text { Female } \\
{ }^{*} \text { age }[45,50)\end{array}$ & $\begin{array}{l}-0.266^{* * *} \\
(0.0766)\end{array}$ & $\begin{array}{l}-0.377^{* * *} \\
(0.0549)\end{array}$ & $\begin{array}{l}0.0547 \\
(0.106)\end{array}$ & $\begin{array}{l}0.0980 \\
(0.195)\end{array}$ \\
\hline $\begin{array}{l}\text { Female } \\
{ }^{*} \text { age }[50,55)\end{array}$ & $\begin{array}{l}-0.158^{* *} \\
(0.0804)\end{array}$ & $\begin{array}{l}-0.136^{* *} \\
(0.0569)\end{array}$ & $\begin{array}{l}0.243^{* *} \\
(0.107)\end{array}$ & $\begin{array}{l}0.194 \\
(0.203)\end{array}$ \\
\hline $\begin{array}{l}\text { Female } \\
\text { *age[55,60) }\end{array}$ & $\begin{array}{l}0.182^{* *} \\
(0.0731)\end{array}$ & $\begin{array}{l}0.170^{* * *} \\
(0.0638)\end{array}$ & $\begin{array}{l}0.150 \\
(0.116)\end{array}$ & $\begin{array}{l}0.0617 \\
(0.242)\end{array}$ \\
\hline $\begin{array}{l}\text { Female } \\
{ }^{*} \text { age }[65,70)\end{array}$ & $\begin{array}{l}-0.327^{* * *} \\
(0.0603)\end{array}$ & $\begin{array}{l}-0.114 \\
(0.0782)\end{array}$ & $\begin{array}{l}-0.109 \\
(0.166)\end{array}$ & $\begin{array}{l}0.0317 \\
(0.296)\end{array}$ \\
\hline $\begin{array}{l}\text { Female } \\
{ }^{*} \text { age }[70,75)\end{array}$ & $\begin{array}{l}-0.583^{* * *} \\
(0.0643)\end{array}$ & $\begin{array}{l}-0.333^{* * *} \\
(0.0970)\end{array}$ & $\begin{array}{l}-0.0613 \\
(0.179)\end{array}$ & $\begin{array}{l}0.135 \\
(0.327)\end{array}$ \\
\hline $\begin{array}{l}\text { Female } \\
\text { *age[75,80) }\end{array}$ & $\begin{array}{l}-0.533^{* * *} \\
(0.0692)\end{array}$ & $\begin{array}{l}-0.466^{* * *} \\
(0.133)\end{array}$ & $\begin{array}{l}0.0874 \\
(0.225)\end{array}$ & $\begin{array}{l}0.0465 \\
(0.356)\end{array}$ \\
\hline $\begin{array}{l}\text { Female } \\
* \text { age }[80+, 100)\end{array}$ & $\begin{array}{l}-0.734^{* * *} \\
(0.0693)\end{array}$ & $\begin{array}{l}-0.386^{* *} \\
(0.173)\end{array}$ & $\begin{array}{l}-0.568^{* *} \\
(0.251)\end{array}$ & $\begin{array}{l}-0.515 \\
(0.398)\end{array}$ \\
\hline$x$ & YES & YES & YES & YES \\
\hline County & YES & YES & YES & YES \\
\hline Observations & 306,558 & 324,610 & 126,747 & 80,629 \\
\hline
\end{tabular}

Notes: 1) The control age group is $[60,65)$

employed and freelancers, the health insurance premium, consisting of the work unit's contribution and that of the individual, should all be paid by the individual." ${ }^{\prime 1}$ Although it is theoretically possible for a person to enroll in insurance, that is, to make a one-off social insurance contribution individually, a considerable amount of health insurance premium must be paid, which might be unaffordable for many families. Moreover, the requirement to pay premiums for at least 15 years reduced the probability of coverage for those over 35 years of age, when the retirement age in China was 50 .

\footnotetext{
${ }^{1}$ Participants who are originally unemployed (including individuals and freelancers) and need to pay basic medical insurance premium for an accumulative total of 15 years stop the payment when they reach the statutory retirement age. If the payment of basic medical insurance premium is for less than the accumulative total of 15 years at the statutory retirement age, participants should continue the payment as required until 15 years thereafter. For reasons such as bankruptcy, restructuring, and institutional reform of state-owned or collective units (including enterprises, the Party, government organizations, and institutions), employees who have left and become self-employed personnel or freelancers should pay the premium continuously (as required before completing formalities of retirement) until the retirement age.
}

Enrolment for those aged above 35 meant that premiums would continue to be paid even after retirement, with the costs borne entirely by the individual. This explains why the gender gap in health insurance coverage increased with age and why gender differences were concentrated in the over50 years old sample in 2005 . Why do elderly women face more difficulties in obtaining health insurance? This is mainly a result of differences in labor participation. It is more likely for elderly women to be laid off or lose their jobs, and more difficult for them to be reemployed. For instance, with the reform of the State-Owned Enterprises (SOEs) in the late 1990s, a large number of workers were laid off or lost their jobs when enterprises were facing increasingly competition [11-14].

\section{Gender differences among different educational groups}

Regarding subgroups by education, gender differences in health insurance are mainly concentrated in the loweducation group. The empirical study of Appleton et.al [15] indicated that women and people who are less educated, less skilled, and middle-aged are more likely to be laid off. During the critical period of the reform of 


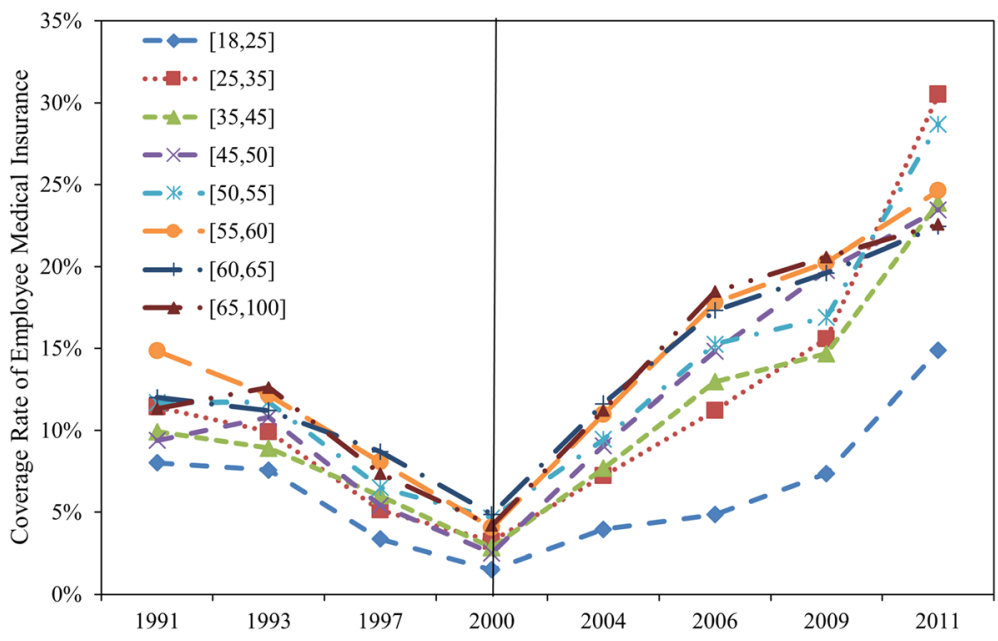

Fig. 4 The Urban Employee Basic Medical Insurance (UEBMI) Coverage Rate: 1991-2011

China's SOEs, less educated women were not competitive in the labor market, which made them vulnerable to changes in the labor market. During this period, a large number of SOEs were restructured or went bankrupt, which caused a significant number of workers to lose their jobs. The group of women with low education was the most affected. On the one hand, there was greater demand for male labor, as China was primarily developing industry at that time. On the other hand, loweducated women were mainly employed in jobs that were highly substitutable with and highly vulnerable to technological advances [16]. The loss of a job meant the loss of health insurance, which increased the medical burden on women and reduced accessibility of health resources. Furthermore, inequitable access to medical resources might directly affect the health of the population.

\section{Gender differences in health insurance and health status}

In the literature, major disputes have always existed regarding the relationship between health insurance and health status. In a few studies, a significant impact of health insurance spending on people's health status and mortality has been found $[17,18]$. However, most empirical studies have indicated that this effect is small [1921]. In the context of universal health insurance in China, numerous recent empirical studies have shown that the gradual implementation of basic health insurance has significantly increased access to medical services and improved the health status of the insured [22-24].

However, with the low proportion of older women being covered by the UEBMI, it was difficult for most of them to receive the necessary medical services. This suggests that the gender gap in health insurance exerted influence on people's health status mainly through its effects on the quality of medical services, including patients' ability to select better hospitals, medicine, and treatments. Specifically, women's higher incidence of nonfatal chronic diseases was probably a result of their not having access to medical services that have the same quality as those enjoyed by men.

Although women tend to live longer compared with men, many studies have shown that their health condition is worse [25-27]. According to the findings of existing literature, the poorer health status of women in developed countries is a result of their higher possibility of suffering from nonfatal chronic diseases such as arthritis, most respiratory illnesses, hypertension, eyesight problems and depression [26]. A new study by Zhang indicated that about $30 \%$ of the gender health gap among Chinese residents could be explained by the difference in the social and economic status between men and women, of which the role of education is most important [27]. However, in our study, the following differences were found from the findings in developed countries. While in the western developed countries, citizens' gender health gap generally tends to disappear gradually, that of the Chinese citizens' do not shrink with age (Fig. 6). As indicated in Fig. 6, women of all ages reported worse health than men, but this gap was especially significant among older people (above 60 ).

\section{Establish a unified health insurance system}

Although China had established a universal health insurance system, there are still obvious inequities remain in different insurance types. The main differences among these major types of insurance relate to their financing and benefits. The UEBMI has the highest level of financing and benefits-significantly higher than those of the other two. Firstly, regarding 

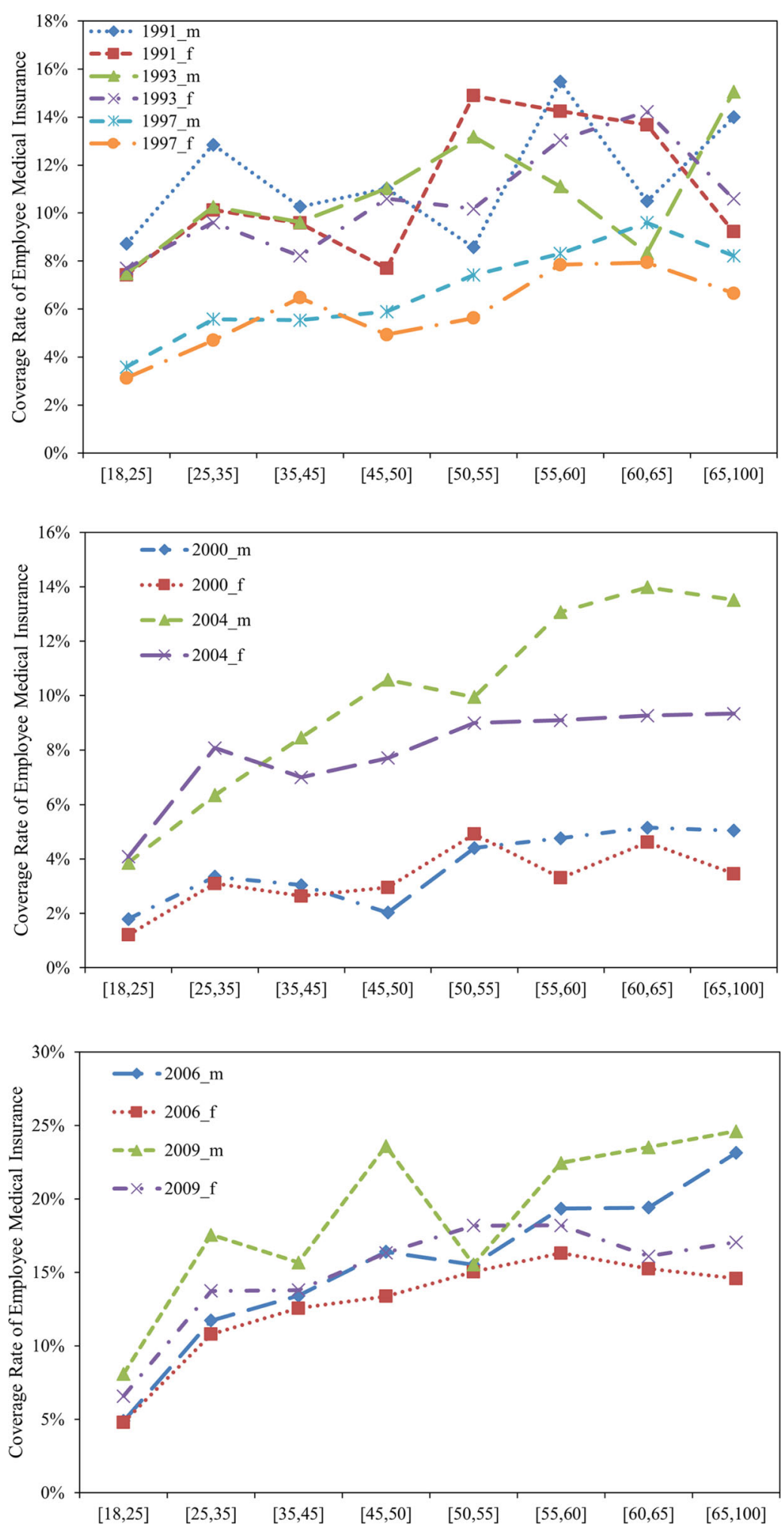

Note: Suffix $m$ is for male; $f$ is for female

Fig. 5 Gender Gap of The Urban Employee Basic Medical Insurance (UEBMI) Coverage Rate: 1991-2009 


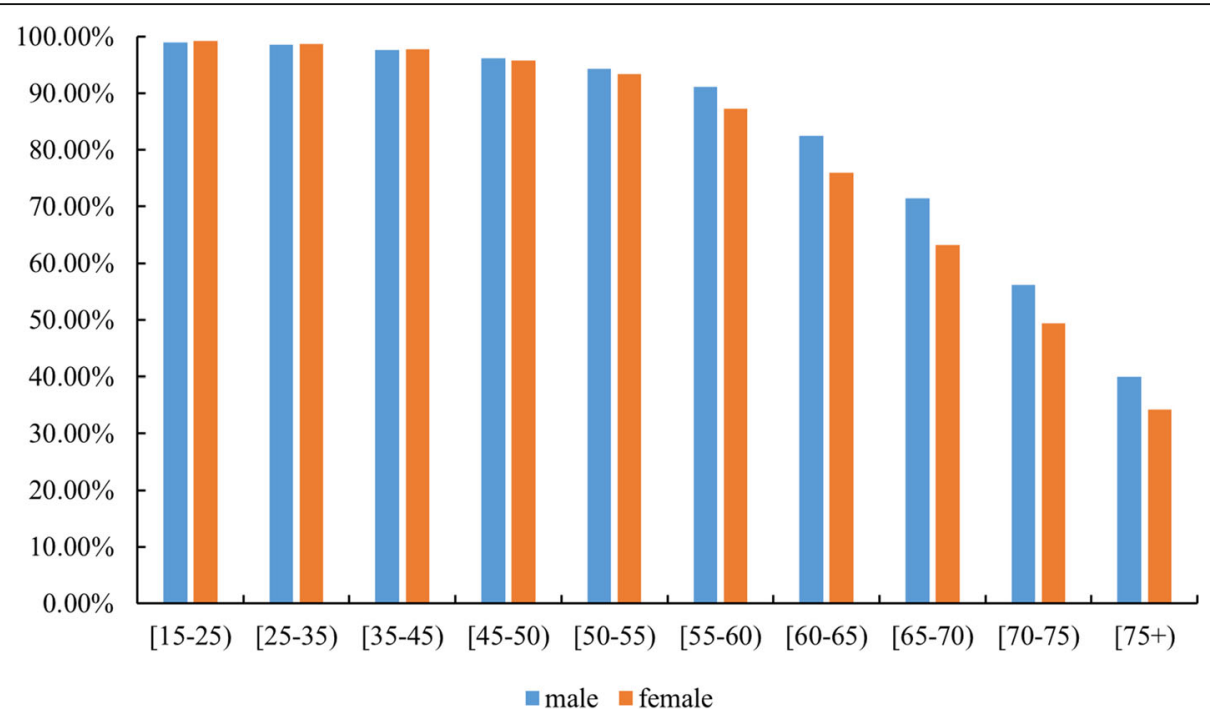

Notes: (1) The vertical axis is the percentage of individuals in good health.

(2) The data are from the sample survey of $1 \%$ of the population in 2005.

Fig. 6 Gender Health Gap

the conditions for enrollment, the UEBMI is mainly available to people who are formally employed, and those who are unemployed or informally employed are mainly covered by the URBMI and the NCMS. Considering the generally low income of URBMI and NCMS enrollees, the central and local governments subsidize these groups of enrollees. Specifically, both the URBMI and NCMS are financed by individual contributions and subsidies from the central and local governments. The UEBMI is financed through enterprise and employee contributions. The premium rate is $8 \%$ of the annual payroll, of which $6 \%$ comes from the employer and $2 \%$, from the employee. Secondly, the annual premiums vary widely among insurance types. The annual per capita premium for the UEBMI in 2018 was 5808.3 yuan, while that for the URBMI and NCMS was only 763.4 yuan [28]. Thirdly, in terms of reimbursement rates, the benefit package for the UEBMI includes inpatient and outpatient care, while for the URBMI reimbursements are for inpatient medical expenses only. Meanwhile, the annual reimbursement ceiling is six times of the average wage of employees in the city for the UEBMI and six times the disposable income of residents for the URBMI [3]. What's more, Regarding the reimbursement ratio, Zhao et al. [29] found that the actual reimbursement ratio for the UEBMI was $75 \%$, while that for the URBMI was $50 \%$. In other words, the portion of the low-income population that is unemployed or informally employed bears more of the burden of health care costs, which clearly results in inequity in the distribution of medical resources due to inequitable health insurance [30-32]. Moreover, some studies have found that the type of the health insurance affects equity in the use of health care services, such that the use of health care services differs among residents covered by different insurance policies [33-36].

The significant gender differences in the coverage of UEBMI in China, especially in the elderly population, may lead this vulnerable group to reduce their consumption of medical resources and further affect their physical health. Low reimbursement rates will reduce the utilization of medical resources by residents, mainly women and the elderly, who are affected by the UEBMI reform. Therefore, in the future improvement of the health insurance system, it is also necessary to improve the benefit level of URBMI and NCMS to reduce the gap between different insurances. Further, it is important to eliminate inequities between different health insurance types. It is generally agreed that China should merge the three schemes into one universal and unified social medical insurance scheme [37-39].

\section{Conclusion}

From the perspective of health insurance reform, this paper explains the gender gap of health insurance and the reason for the wider gap among older people. Our study indicates that since the UEBMI in China mainly covers people with formal jobs, the lower labor participation rate (even much lower in formal jobs) of women leads to their greater difficulty in obtaining health insurance. However, since older women were more likely to 
be fired or less likely to find a job during the UEBMI reform, they were less likely to be insured. In fact, it was the combined effect of the UEBMI system and the labor market conditions at that time that resulted in a lower proportion of older women obtaining UEBMI.

We used a large volume of data from a demographic survey to verify our conjecture. First, based on the data from the survey of $1 \%$ of the population in 2005 and in 2015 , it is found that the proportion of women aged over 50 (2005) or 60 (2015) covered under the UEBMI was much lower than that of men, while the gap between young women and men was comparatively narrower. Furthermore, using the 1991-2011 data of CHNS, we find that the disadvantages of women in health insurance coverage only emerged after the implementation of the UEBMI reform in 1998. This further verifies our previous conjecture.

\section{Supplementary Information}

The online version contains supplementary material available at https://doi. org/10.1186/s12939-021-01383-9.

Additional file 1: Table 1A. Gender Gap in Health Insurance Coverage: Based on Population Census in 2005. Table 2A. Gender Gap in Health Insurance Coverage: Based on Population Census in 2015.

\section{Abbreviations}

SHI: Social health insurance; UEBMI: Urban Employee Basic Medical Insurance; URBMI: Urban Resident Basic Medical Insurance; NCMS: New Cooperative Medical Scheme; CHNS: China Health and Nutrition Survey; SOEs: Stateowned Enterprises

\section{Authors' contributions}

MZ led the study. He designed the study, led the data collection, analysis, and interpretation. SZ contributed to the study design, provided input into the data analysis, and wrote the first draft of the manuscript. ZZ contributed to the study design, reviewed the manuscript and helped the writing of the final draft manuscript. All authors read and approved the final manuscript.

\section{Funding}

This paper was funded by the National Natural Science Foundation of China, "Health Care for the Elderly, Medical Expenditure and Savings" (71773080).

\section{Availability of data and materials}

The datasets generated and/or analysed during the current study are not publicly available due the data confidentiality agreement, but are available from the corresponding author on reasonable request.

\section{Ethics approval and consent to participate}

Not applicable.

\section{Consent for publication}

Not applicable.

\section{Competing interests}

The authors declare that they have no competing interests.

\section{Author details}

${ }^{1}$ School of Public Administration, Southwestern University of Finance and Economics, Chengdu, Sichuan, China. ${ }^{2}$ School of Economics, Sichuan University, Chengdu, China.
Received: 10 August 2020 Accepted: 10 January 2021

Published online: 01 February 2021

\section{References}

1. Xiong X, Zhang Z, Ren J, Zhang J, Pan X, Zhang L, et al. Impact of universal medical insurance system on the accessibility of medical service supply and affordability of patients in China. PLoS One. 2018;13(3):e0193273. https://doi. org/10.1371/journal.pone.0193273.

2. Yu H. Universal health insurance coverage for 1.3 billion people: What accounts for China's success? Health Policy. 2015;119(9):1145-52. https://doi. org/10.1016/j.healthpol.2015.07.008 PMID: 2625132.

3. Yip CM, Hsiao WC, Chen W, Hu S, Ma J, Maynard A. Early appraisal of China's huge and complex health-care reforms. Lancet. 2012;379(9818):833-42. https://doi.org/10.1016/S0140-6736(11)61880-1 PMID: 22386036.

4. Xu L, Wang Y, Collins CD, Tang S. Urban health insurance reform and coverage in China using data from National Health Services Surveys in 1998 and 2003. BMC Health Serv Res. 2007;7(1):1-14. https://doi.org/10.1186/ 1472-6963-7-37 PMID: 17335584

5. National Bureau of Statistics, China. Statistical bulletin on national economic and social development. 2019; http://www.stats.gov.cn/tjsj/zxfb/202002/t202 00228_1728913.html

6. Liu H, Dai WD, Xiang YH. A study on the fairness of benefit from basic medical insurance for urban and rural residents from the perspective of public service equalization. Insurance Studies. 2020;05:110-27.

7. Xiong YG, Huang J. A study of inequality in medical service utilization in urban and rural areas in China-an empirical analysis of CHARLS data. Population Journal. 2016;38(06):62-76

8. Zhou Q, Tian S, Pan J. Inequality under parity-theoretical and empirical research on the fairness of urban residents' basic medical insurance benefits. Econ Res J. 2016;51(06):172-85.

9. Yip W, Fu H, Chen AT, Zhai T, Jian W, Xu R, Pan J, Hu M, Zhou Z, Chen Q, et al. 10 years of health-care reform in China: Progress and gaps in universal health coverage. Lancet. 2019;1:192-204.

10. Liu Y. Reforming China's urban health insurance system. Health Policy. 2002; 60(2):133-50. https://doi.org/10.1016/S0168-8510(01)00207-X PMID: 11897373

11. Song $Y$, Bian $Y$. Gender differences in the use of health care in China: crosssectional analysis. Int J Equity Health. 2014;13:8. https://doi.org/10.1186/ 1475-9276-13-8.

12. Cui B, Li WP. Health gender inequality and gender-aware analysis on public health budget of China. Population Dev. 2009;15:60.

13. Li CX, Wu ZC, Xu L, Gao J. Gender differences in medical expenditure in China. Chinese Health Eco Magazine. 2006;25:46-8.

14. Meng Q, Rehnberg C, Zhuang N, Bian Y, Tomson G, Tang S. The impact of urban health insurance reform on hospital charges: a case study from two cities in China. Health Policy. 2004;68:197-209. https://doi.org/10.1016/j. healthpol.2003.09.010.

15. Appleton S, Knight J, Song L, et al. Labor retrenchment in China: determinants and consequences. China Econ Rev. 2002;13(2):252-75.

16. Ross CE, Masters RK, Hummer RA. Education and the gender gaps in health and mortality. Demography. 2012;49(4):1157-83.

17. Card D, Dobkin C, Maestas N. Does Medicare Save Lives? Q J Econ. 2009; 124(2):597-636.

18. Doyle JJ. Returns to local-area health care spending: evidence from health shocks to patients far from home. Am Econ J-Appl Econ. 2011;3(3):221-43.

19. Brook JR, Rogers GW, et al. Does free care improve adults' health? Results from a randomized controlled trial. N Engl J Med. 1983;309(23):1426.

20. Fisher ES. The implications of regional variations in medicare spending. Part 1: the content, quality, and accessibility of care. Ann Intern Med. 2003; 138(4):288-322.

21. Finkelstein A, Mcknight R. What did Medicare do? The initial impact of Medicare on mortality and out of pocket medical spending. J Public Econ. 2008;92(7):1644-68.

22. Lei $X$, Lin W. The new cooperative medical scheme in rural China: does more coverage mean more service and better health? Health Econ. 2010; 18(S2):S25-46

23. Chen $Y$, Jin GZ. Does health insurance coverage lead to better health and educational outcomes? Evidence from rural China. NBER Working Paper No. 16417. J Health Econ. 2012;31(1):1.

24. Liu H, Zhao Z. Does health insurance matter? Evidence from China's urban resident basic medical insurance. J Comp Econ. 2014;42(4):1007-20. 
25. Nathanson CA. IIIness and the feminine role: a theoretical review. Soc Sci Med. 1975;9(2):57-62.

26. Paxson CC. Sex differences in morbidity and mortality. Demography. 2005; 42(2):189-214

27. Zhang H, Bagod'Uva T, Van DE. The gender health gap in China: a decomposition analysis. Econ Human Biol. 2015;18:13-26.

28. National Bureau of Statistics, China. Revenue and expenses of urban basic medical care insurance by region. 2019. http:/www.stats.gov.cn/tjjs/ndsj/2 019/indexch.htm

29. Zhao SY, Zang WB, Yin QS. Welfare effects of health care coverage levels. Econ Res J. 2015;50(08):130-45.

30. Chen Y, Yin Z, Xie Q. Suggestions to ameliorate the inequity in urban/rural allocation of healthcare resources in China. Int J Equity Health. 2014;13:34. https://doi.org/10.1186/1475-9276-13-34.

31. Sun J, Luo H. Evaluation on equality and efficiency of health resources allocation and health services utilization in China. Int J Equity Health. 2017; 16:127. https://doi.org/10.1186/s12939-017-0614-y.

32. Xie J, Fang P. Study on the configuration fairness and the utilization efficiency of inter-provincial health resource in China. Chin Health Econ. 2013;32(1):60-2

33. Zhou Z, Gao J, Fox A, Rao K, Xu K, Xu L, Zhang Y. Measuring the equity of inpatient utilization in Chinese rural areas. BMC Health Serv Res. 2011;11:201. https://doi.org/10.1186/1472-6963-11-201.

34. Long Q, Xu L, Bekedam H, et al. Changes in health expenditures in China in 2000s: has the health system reform improved affordability. Int J Equity Health. 2013:12:40. https://doi.org/10.1186/1475-9276-12-40.

35. Fan X, Kumar MB, Zhou Z, et al. Influence of China's 2009 healthcare reform on the utilisation of continuum of care for maternal health services: evidence from two cross-sectional household surveys in Shaanxi Province. Int J Equity Health. 2020;19:100. https://doi.org/10.1186/s12939-020-01179-3.

36. Zhou Z, Zhu L, Zhou Z, et al. The effects of China's urban basic medical insurance schemes on the equity of health service utilisation: evidence from Shaanxi Province. Int J Equity Health. 2014;13:23. https://doi.org/10.1186/ 1475-9276-13-23

37. Pan XF, Xu J, Meng Q. Integrating social health insurance systems in China. Lancet. 2016;387(10025):1274-5. https://doi.org/10.1016/S01406736(16)30021-6.

38. Meng Q, Fang H, Liu X, Yuan B, Xu J. Consolidating the social health insurance schemes in China: Towards an equitable and efficient health system. Lancet. 2015;386(10002):1484-92. https://doi.org/10.1016/S01406736(15)00342-6 PMID: 26466052

39. Gu X. The choice of system for universal health insurance is crucial. China Soc Security. 2007;1:26-7.

\section{Publisher's Note}

Springer Nature remains neutral with regard to jurisdictional claims in published maps and institutional affiliations.

Ready to submit your research? Choose BMC and benefit from:

- fast, convenient online submission

- thorough peer review by experienced researchers in your field

- rapid publication on acceptance

- support for research data, including large and complex data types

- gold Open Access which fosters wider collaboration and increased citations

- maximum visibility for your research: over $100 \mathrm{M}$ website views per year

At $\mathrm{BMC}$, research is always in progress.

Learn more biomedcentral.com/submissions 